years ago: "It will be realized that with an infantile mortality-rate of 64 per thousand no spectacular improvement can be expected"?. In 1942, the infantile mortality-rate in England and Wales fell to 49 -lower than in any year before. This in the third year of a major war, with a rising birth-rate, is not merely spectacular; it is an achievement without parallel in history. The newer knowledge of nutrition has been applied and is justified by the results. Dr. Magee justly gave the credit to those who, brick by brick, have built up this modern knowledge. The first part of this meeting may have seemed a tedious fussing about details; but on these details policy must be based. Much remains to be done, particularly on this question of the relation of breast feeding to the nutrition of the mother.

The national milk scheme and provision of vitamin preparations are not isolated benefits to a small section of the people. With the provision of milk in schools and school meals, they are outstanding steps in the general policy of food control which aims at ensuring food according to physiological needs ; they may be the beginnings of a future world policy. It seems that the Food Conference at Hot Springs will not descend to bargains to limit production similar to the wheat and sugar schemes of the past, but will fulfil its promise that the peoples of the world will work together. to increase production and adjust distribution to abolish want. If so, our achievement in the midst of this War may stand as a record for all time; not because the mortality of infants, breastor bottle-fed, will not fall far below 49 per thousand, but because a major cause of war will be no more.

${ }^{1}$ Fost, A. S., and Thomas, S. Y., J. Min, Agric., 45, 452 (1938).

2 Grulee, C. G., et al., Trans. Sect. Poediatr. Amer. Med. Ass. (1934).

${ }^{3}$ Jeans, P. C., J. Amer. Med. A8soc., 120, 913 (1942).

4 Catherwood, R., and Stearns, J., J. Biol. Chem., 119, 201 (1937).

Ellison, J. B., and Moore, T., Biochem. J., 31, 165 (1937).

- McCance, R. A., Widdowson, E. M., and Verdoe-Roe, C. M., J. Hyg. 38, 597 (1938).

- Annual Report of the Chief Medical Officer of the Ministry of Health for the year 1933, p. 9.

\section{INDIA'S MINERAL RESOURCES}

\section{By SIR LEWIS FERMOR, O.B.E., F.R.S.}

IKE the British Association, the Indian Science 1 Congress Association meets annually, moving from one important centre to another; this year the Association met in Calcutta for its thirtieth session. Mr. D. N. Wadia, owing to unforeseen circumstances, created a record by holding the office of general president for a second term. His address as general president during the first of these years was concerned chiefly with the geological origins of India (see Nature, December 19, 1942, p. 725). His second address (see Nature, May 15, p. 548) dealt with more general matters, only touching on the mineral resources of India. The president of the Sec. tion of Geology and Geography, however, Dr. J. A. Dunn, of the Geological Survey of India, gave an address on "Suggestions for the Future Development of India's Mineral Resources" (Proc. 30th Ind. Sci. Cong., Part II, Section IV, pp. 1-22; 1943). This is a subject of interest to all who have been concerned with Indian minerals, and one that has, therefore, been discussed previously on numerous occasions. Dr. Dunn has, however, devoted so much of his career in India to the survey and study in the field, as well as in the laboratory, of several of India's principal minerals, that his views must be of value.
Any suggestions for the future development of the mineral resources of a country must be preceded by a statistical stocktaking. The fog of war has, however, descended upon India's statistics of mineral production, the latest published review being that for 1938. This withholding of statistics is in contrast to the practice during the War of 1914-18, when the usual reviews were published annually. The necessity for the present statistical secrecy seems doubtful. Dr. Dunn has met the situation, in what will be to some the most interesting part of his address, with a table showing the relative pre-war mineral production of India and of the principal nations. This table shows the relative production of fifty-four metal and mineral substances by India, the British Empire, the United States, the U.S.S.R., France, Germany, Italy and Japan. The production is not shown by actual figures, but by symbols indicating degree of excess, sufficiency or deficiency, the terms used referring, of course, to a country's output compared with its internal needs, excess justifying export, and deficiency causing import.

According to this table, India has world control in mica, monazite and titanium (ilmenite); a large excess of chromite, kyanite and sillimanite, and manganese ore; an excess of beryllium ore, columbite-tantalite, gold and magnesite; and a sufficiency of barium, bauxite, coal, felspar, fuller's earth and bentonite, graphite, gypsum, iron ore, salt, talc and tungsten; whereas supplies of all other minerals are deficient or negligible. Although all would not apply these labels as used by Dr. Dunn, they give an idea of India's position with reference to the world's mineral supplies, and in particular show which minerals she can afford to export, which she needs for internal use, and which she must import if she is to attain and maintain a balanced industrial economy.

The one mineral of which the classification might be altered is gold, in view of the fact that over a long period of years India was a sink for gold obtained mainly by import; and as the Indian output of new gold (from the Kolar goldfield) is a small one, such exports of gold as have taken place since Britain and India left the gold standard have been mainly from hoards of gold previously imported.

Deductions to be drawn from statistics of mineral production, exports and imports, concerning the metal requirements of industrialized countries, are liable to be vitiated, at least partially, by the increasing part that scrap metal plays in modern industry, adequate statistics of which are not pub. lished by any country except the United States of America. Dr. Dunn does not refer to this problem, probably because it has not yet arisen to any major degree for India, which has not long become one of the industrially developed nations. The above reference to gold shows that hoards of precious metals such as gold and silver-although not to be regarded as in any sense a form of scrap-play a similar part. to accumulations of scrap metal in tending to vitiate deductions concerning the mineral economy of $a$ country based on the study of mineral statistics that do not take account of the existence of accumulated stocks of metals, either as such or in the form of scrap metal available for return to industry.

Dr. Dunn next discusses the distribution of minerals in India, a country that illustrates in miniature the world's unequal distribution of useful minerals. For in India 40 per cent of the total mineral output comes from one province, Bihar, with its large 
deposits of coal, iron ore, limestone and mica, and its smaller quantities of copper ore, chromite, bauxite, kyanite and manganese ore. Advocates of the subdivision of India forget the witness of geology and minerals; for all parts of India are economically interdependent, requiring a co-ordinated mineral policy applicable to the country as a unit. Amplifying Dr. Dunn, one may say that from the mineral point of view the effects of the mutilation of the Indian geological unit by the amputation of the Burmese arm must not be enhanced by the additional sub. division of India, without provision for some form of central geological and mineral control.

The major part of this address is that in which Dr. Dunn discusses each mineral in turn with reference to the possibilities of expansion of production and treatment in India, if economically suitable. Quoting the author :

"At least four minerals now mined in India-mica, manganese ore, ilmenite and monazite-are of great importance to the world's industries, but to date almost their entire production has been exported in the unmanufactured state. These minerals must continue to be exported, but it is eminently desirable that much of the manufacturing processes through which they eventually pass should be completed in India before export. Within this country [India] there is nothing to prevent the gradual expansion of the micanite trade from mica splittings, or the manufacture of titanium white from ilmenite, or the extraction of thorium oxide and cerium from monazite, or even the smelting of much of our manganese ore to ferromanganese."

To this Dr. Dunn very wisely adds a rider : "the main problem would be in ensuring that other countries accept the Indian manufactured material in place of the raw material". The danger in such cases always is that an importing country, rather than lose the benefits of treating imported raw materials, would if possible turn to an alternative source of supply from another country, helping its development if necessary.

Among other mineral substances discussed sulphur may be mentioned, for one of the most. im. portant industrial requirements of India is an adequate supply of sulphuric acid, the keystone to so much chemical development. Until recently this commodity has been manufactured from imported sulphur. During the present War, the situation has been helped by the development of the natural sulphur deposits of Baluchistan, due to the initiative of Sir Cyril Fox as director of the Geological Survey of India. But the future important source of sulphur in India is likely to be the extensive deposits of gypsum, particularly those of the Salt Range in the Punjab.

In the remainder of his address Dr. Dunn discusses a number of other problems, such as the stimulation of prospecting, geophysical prospecting, and the possibilities of State aid in the development of the mineral industry. $\mathrm{He}$ also recognizes that in addition to a national mineral policy there is an international aspect of such policy, and that if India is to take her proper position among the nations she will have to conform to such general scheme of international mineral policy as may emerge from the post-war political framework. The discussion of such a policy has, of course, been initiated by the British Association, and the problem is now under consideration by the Mineral Resources Committee of that body appointed specially for the purpose.

\section{THE SEARCH FOR NEW INSECTICIDES}

\author{
By DR. J. R. BUSVINE \\ Ministry of Health Entomological Laboratory
}

$T$ HE amusing definition of a specialist as "one who learns more and more about less and less" does not hold for the specialist in applied science. On the contrary, so far as I have observed in applied biology, it is a curious paradox that concentration on a single problem often requires the widest superficial knowledge of many subjects. For example, for the past three years I have been studying the effect of new insecticides on the louse. That would appear to be a fairly specialized problem requiring merely a familiarity with the biology of the louse and the physical and chemical properties of the organic chemicals proposed as insecticides. Actually the research led to a consideration of such diverse subjects as the psychology of the louse (and to some extent of the infested men who came to us for treatment), the risks of dermatitis from various chemicals and the possible carcinogenicity of oil diluents. The powers of absorption and retention of cotton, wool and cellulose acetate underwear were considered, and practical problems of laundering and dry-cleaning (especially the preparation of emulsions and the use of large centrifuges) came into the picture. Finally, one had to learn a little of such diverse subjects as army hygiene and women's hair-dressing styles.

It will be realized that, with such a bizarre series of ancillary problems, the biologist at work on a special control problem has little time to look for new insecticides; he can only test those suggested by others.

A search for new insecticidal compounds has been carried out since 1932 by the United States Department of Agriculture (about three thousand sub. stances have been tested on a variety of insects). Apart from this, most of the work has been done in the laboratories of industrial firms. Very little of this work is published but, so far as one can judge, it is largely of an empirical nature. That is to say, of the large number of chemicals tested for suitability as insecticides, the majority are chosen on grounds of availability and the others because of chemical affinity to recognized insecticides. The reasons for the toxicity of these established insecticides were not investigated.

Fundamental research on the mode of action of insecticides has been neglected because it is difficult, and therefore slow. Many administrative men, both in industry and in Government departments, consider the work too academic. They pin their faith on systematized empiricism for getting quicker results. Opposing this extremely pragmatic outlook are those who have consistently urged that fundamental work is fruitful in practice. Certainly it must be admitted that the intensive empirical work of the last decade has left us, in war-time, with very few synthetic substitutes for the vegetable insecticides imported from abroad. It would seem that there is a very strong case for extending the fundamental research on insect toxicology.

As has been implied, the way in which insecticides act is very little understood. The subject can be explored by three kinds of investigation.

1. Quantitative Experiments. This type of research is, perhaps, easier than the others, because the 